\title{
Metacognitive Myopia: Bentuk Khusus Kebutaan Metakognitif dalam Konteks Perkuliahan Daring di Era Pandemi
}

\author{
Surya Sari Faradiba ${ }^{1}$, Alifiani $^{2}$, Siti Nurul Hasana ${ }^{3}$ \\ ${ }^{1,2,3}$ Program Studi Magister Pendidikan Matematika, Pascasarjana, Universitas Islam Malang, \\ Jl. Mayjen Haryono 193, Malang, Indonesia \\ suryasarifaradiba@unisma.ac.id
}

\begin{abstract}
This study aims to explore metacognitive myopia at each stage of problem solving in the context of online learning. The research subject is a student of the Mathematics Education study program. The research instrument consisted of real analysis problem solving and interview guidelines. In this study, subjects were asked to work on math problems individually and then interviewed online to confirm the occurrence of metacognitive myopia. The results showed that the subject experienced metacognitive myopia which was marked by the presence of a red flag type of error detection (ED) at the implementation stage of problem solving. This phenomenon is experienced by students who fail to realize that there are errors in certain steps that are not directly related to problem solving, while in steps that are directly related there are no problems. In this case, students take information for granted regarding the definition of a function and fail to distinguish whether the information is valid or invalid. However, the subject did not experience an error in determining an invertible function or not. The subject understands the condition of an invertible function, namely that the function must be one and onto. Further research is needed to deepen studies related to metacognitive myopia by involving more subjects.
\end{abstract}

Keywords: Real Analysis, Error Detection, Function, Invertible, Metacognitive Myopia

\begin{abstract}
Abstrak
Penelitian ini bertujuan untuk mengeksplorasi metacognitive myopia pada setiap tahapan pemecahan masalah dalam konteks pembelajaran daring. Subjek penelitian adalah seorang mahasiswa program studi Pendidikan matematika. Instrumen penelitian terdiri dari soal pemecahan masalah Analisis Riil dan pedoman wawancara. Dalam penelitian ini, subjek diminta mengerjakan masalah matematika secara individu untuk selanjutnya diwawancarai secara daring untuk mengonfirmasi terjadinya metacognitive myopia. Hasil penelitian menunjukkan bahwa subjek mengalami metacognitive myopia yang ditandai dengan adanya red flag jenis error detection (ED) pada tahap implementasi pemecahan masalah. Fenomena ini dialami oleh mahasiswa yang gagal menyadari adanya kesalahan pada langkah tertentu yang tidak terkait secara langsung dengan pemecahan masalah, sementara pada langkah yang terkait secara langsung tidak ada masalah. Pada kasus ini, mahasiswa menerima informasi begitu saja terkait definisi suatu fungsi dan gagal membedakan apakah informasi tersebut valid atau tidak valid. Namun, subjek tidak mengalami kesalahan dalam menentukan suatu fungsi invertible atau tidak. Subjek memahami syarat suatu fungsi invertible yakni fungsi tersebut harus satu satu dan onto. Penelitian lebih lanjut dibutuhkan untuk memperdalam kajian terkait metacognitive myopia dengan melibatkan subjek lebih banyak.
\end{abstract}

Kata kunci: Analisis Riil, Error Detection, Fungsi, Invertible, Metacognitive Myopia

Copyright (c) 2022 Surya Sari Faradiba, Alifiani, Siti Nurul Hasana

$\triangle$ Corresponding author: Alfi Rahmawati

Email Address: suryasarifaradiba@unisma.ac.id (Jl. Mayjen Haryono 193, Malang, Indonesia)

Received 15 November 2021, Accepted 18 January 2021, Published 18 January 2022

\section{PENDAHULUAN}

Indonesia mengonfirmasi adanya kasus pertama Covid-19 pada 2 Maret 2020 (Setiawan, 2020; Tosepu et al., 2020). Pandemi telah mengubah cara hidup manusia, termasuk proses belajar mengajar (Cauchemez et al., 2009). Semua satuan pendidikan di Indonesia, termasuk perguruan tinggi mengeluarkan kebijakan belajar di rumah dan menerapkan pembelajaran daring (Irfan et al., 2020). Dengan diterapkannya kebijakan tersebut, banyak dosen, mulai menggunakan platform sistem 
pengelolaan pembelajaran (LMS) serta video conference untuk membantu kegiatan pembelajaran matematika (Dwi et al., n.d.; Gunawan et al., 2020).

Dalam masa pandemi, memang pembelajaran daring merupakan solusi alternatif karena dapat digunakan dimana saja dan kapan saja (Basilaia \& Kvavadze, 2020; Nakamura et al., 2018). Namun, implementasi pembelajaran daring juga dapat menimbulkan berbagai masalah, baik masalah teknis (seperti jaringan internet yang tidak stabil dan perangkat yang kurang mendukung) maupun non teknis (seperti motivasi belajar dan kemandirian belajar, dan sebagainya) (Hung \& Chou, 2015). Dalam masa ini, kemampuan metakognitif mahasiswa memainkan peran yang penting. Mahasiswa yang memiliki keterampilan metakognitif yang baik akan memiliki performa yang lebih bagus dalam melakukan tugas. Selain itu, mahasiswa membutuhkan ketrampilan metakognitif dalam pembelajaran untuk berpikir secara proaktif, melakukan berbagai tindakan untuk memahami suatu konsep, dan merefleksikan diri (Ergen \& Kanadli, 2017). Namun, sayangnya tidak semua mahasiswa memiliki ketrampilan ini. Dalam prosesnya, mahasiswa seringkali mengalami kegagalan metakognitif.

Sejauh ini, belum ada teori kegagalan metakognitif yang menjelaskan kegagalan dalam pembelajaran daring. Di samping itu, penelitian tentang hambatan dalam pembelajaran daring yang sudah ada masih terbatas dalam situasi di luar pandemi (Eady \& Lockyer, 2013), sedangkan penelitian selama pandemi belum banyak dilakukan. Adapun urgensi penelitian ini adalah untuk melengkapi teori kegagalan metakognitif yang mengungkapkan tentang hambatan pada pembelajaran matematika secara tatap muka (Faradiba et al., 2019; Faradiba \& Alifiani, 2020; Goos \& Merrilyn, 2002).

Salah satu mata kuliah yang diajarkan secara daring di tingkat perguruan tinggi, khususnya di prodi Pendidikan Matematika adalah Analisis Riil. Mata kuliah ini berisi konsep-konsep aljabar serta bilangan. Analisis Riil sesungguhnya lebih menekankan pada teori-teori fundamental dan pembuktian teorema-teorema dan sedikit tentang aspek perhitungan. Mahasiswa terkadang mengalami kesulitan dalam proses pembuktian teorema dalam matematika. Penelitian yang ada sebatas mengkaji penyebab kesulitan siswa dalam belajar Analisis Riil pada masa pandemi, yang dapat diidentifikasi sebagai faktor internal dan eksternal (Sari et al., 2021). Metacognitive myopia dalam perkuliahan Analisis Riil perlu untuk dikaji karena untuk mempelajari materi yang ada dalam mata kuliah ini membutuhkan kemampuan kognitif tingkat tinggi, seperti kemampuan analisis, sintesis, dan evaluasi (Utami, 2017).

Sejauh ini, ada tiga kegagalan metakognitif dalam pembelajaran tatap muka yaitu mirage, vandalisme dan blindness (Goos \& Merrilyn, 2002). Mirage terjadi ketika mahasiswa tidak menyadari adanya kesulitan, mengabaikan strategi yang berguna, mengubah kalkulasi yang sebetulnya sudah benar, dan menolak jawaban yang benar. Vandalisme terjadi ketika seorang siswa mengatasi kebuntuan dengan melakukan tindakan destruktif dengan menerapkan struktur konseptual secara tidak tepat. Blindness terjadi ketika mahasiswa gagal menyadari adanya kesalahan, misalnya, mahasiswa yang menggunakan strategi yang tidak tepat atau mengabaikan adanya kesalahan perhitungan. Dalam hal ini, metacognitive myopia sebagai bentuk lebih khusus dari kebutaan metakognitif (metacognitive 
Metacognitive Myopia: Bentuk Khusus Kebutaan Metakognitif dalam Konteks Perkuliahan Daring di Era Pandemi, Surya Sari Faradiba, Alifiani, Siti Nurul Hasana

blindness). Fenomena ini dialami oleh mahasiswa yang gagal menyadari adanya kesalahan pada langkah tertentu yang tidak terkait secara langsung dengan pemecahan masalah, sementara pada langkah yang terkait secara langsung tidak ada masalah. Pada kasus ini, mahasiswa menerima informasi begitu saja dan gagal membedakan antara informasi yang valid dan tidak valid (Fiedler, 2019; Fiedler et al., 2018). Sejauh ini belum ada penelitian yang membahas metacognitive myopia khususnya dalam konteks pembelajaran matematika di tingkat perguruan tinggi. Penelitian yang sudah ada baru membahas berbagai metode atau media yang digunakan dalam pembelajaran Analisis Riil di tingkat perguruan tinggi, seperti pembelajaran kooperatif tipe group investigastion (Utami, 2017), Media Google Classroom (Ridwan \& Umam, 2021), dan Media E-Learning Berbasis Youtube (Panggabean \& Harahap, 2018). Oleh karena itu, penelitian ini mengeksplorasi metacognitive myopia yang dialami mahasiswa dalam perkuliahan Analisis Riil secara daring.

\section{METODE}

Penelitian ini merupakan penelitian kualitatif dengan jenis studi kasus. Kasus yang dipelajari adalah metacognitive myopia yang dihadapi mahasiswa selama menyelesaikan masalah matematika dalam pembelajaran daring. Teknik sampling yang digunakan untuk memilih subjek penelitian adalah convenience sampling. Kriteria subjek penelitian meliputi: (a) subjek adalah mahasiswa S1 Pendidikan Matematika (minimal semester 5); (b) subjek tidak mengalami dyscalculia maupun gangguan belajar lain menurut kriteria DSM V (DSM-5, n.d.); (c) subjek lulus semua mata kuliah di semester sebelumnya; (d) subjek memiliki sarana dan prasarana yang memadai untuk mengikuti pembelajaran daring. Adapun masalah yang digunakan dalam penelitian ini adalah sebagai berikut:

Diketahui $f: Z \rightarrow Z, f(x)=\left\{\begin{array}{c}2 x-1, \text { jika } x \text { bilangan genap } \\ 2 x, \text { jika } x \text { bilangan ganjil }\end{array}\right.$

a. Apakah $f$ fungsi satu satu?

b. Apakah $f$ fungsi onto?

c. Apakah $f$ fungsi yang invertible?

Adapun Metacognitive Myopia dapat mengarah pada beberapa faktor yang mempengaruhi problem-solving seperti deteksi adanya kesalahan dalam proses problem-solving (Error Detection/ED), tidak adanya kemajuan dalam proses menemukan solusi (Lack of Progress/LP), dan keambiguan pada jawaban akhir (Anomalous Result/AR) (Goos \& Merrilyn, 2002). Ketiga faktor tersebut sering disebut dengan red flag. Indikator Metacognitive Myopia pada tahapan memahami masalah berdasarkan red flag dapat dilihat pada Tabel 1 . 
Tabel 1. Indikator Metacognitive Myopia pada Fase Memahami/Understanding (U)

\begin{tabular}{|l|l|}
\hline \multicolumn{1}{|c|}{ Tipe Red Flag } & \multicolumn{1}{c|}{ Indikator Metacognitive Myopia } \\
\hline $\begin{array}{l}\text { Lack of Progress } \\
\text { (LP-U) }\end{array}$ & $\begin{array}{l}\text { Subjek tidak menyadari bahwa mereka mengalami kesulitan dalam } \\
\text { memvalidasi apa yang ditanyakan }\end{array}$ \\
\hline $\begin{array}{l}\text { Error Detection (ED- } \\
\text { U) }\end{array}$ & $\begin{array}{l}\text { Subjek tidak menyadari bahwa mereka melakukan kesalahan dalam } \\
\text { proses memvalidasi apa yang ditanyakan }\end{array}$ \\
\hline $\begin{array}{l}\text { Anomalous Result } \\
\text { (AR-U) }\end{array}$ & $\begin{array}{l}\text { Subjek tidak menyadari bahwa kesalahan/ketidaksesuaian yang } \\
\text { mereka temukan dalam memvalidasi masalah sebenarnya tidak ada }\end{array}$ \\
\hline
\end{tabular}

Selanjutnya, Tabel 2 berisi deskripsi Metacognitive Myopia yang disebabkan oleh red flag ketika subjek menganalisis masalah. Menganalisis masalah adalah kegiatan memikirkan materi yang berkaitan dengan masalah

Tabel 2. Indikator Metacognitive Myopia pada Fase Analisis/Analyzing (A)

\begin{tabular}{|l|l|}
\hline \multicolumn{1}{|c|}{ Tipe Red Flag } & \multicolumn{1}{c|}{ Indikator Metacognitive Myopia } \\
\hline $\begin{array}{l}\text { Lack of Progress } \\
\text { (LP-A) }\end{array}$ & $\begin{array}{l}\text { Subjek tidak menyadari bahwa mereka mengalami kesulitan memvalidasi } \\
\text { hubungan antara apa yang diketahui dan apa yang ditanyakan. }\end{array}$ \\
\hline $\begin{array}{l}\text { Error Detection (ED- } \\
\text { A) }\end{array}$ & $\begin{array}{l}\text { Subjek tidak menyadari bahwa mereka melakukan kesalahan dalam } \\
\text { memvalidasi hubungan antara apa yang diketahui dan apa yang ditanyakan. }\end{array}$ \\
\hline $\begin{array}{l}\text { Anomalous Result } \\
\text { (AR-A) }\end{array}$ & $\begin{array}{l}\text { Subjek tidak menyadari bahwa kesalahan/ketidaksesuaian yang mereka } \\
\text { temukan ketika memvalidasi hubungan antara apa yang diketahui dan apa } \\
\text { yang ditanyakan dalam menyelesaikan masalah tidak ada. }\end{array}$ \\
\hline
\end{tabular}

Tabel 3 berisi deskripsi Metacognitive Myopia yang disebabkan oleh red flag saat subjek mengeksplorasi masalah. Kegiatan pada fase ini merupakan kegiatan yang menggunakan informasi yang relevan dari dua fase sebelumnya.

Tabel 3. Indikator Metacognitive Myopia pada fase Eksplorasi/Exploring (E)

\begin{tabular}{|l|l|}
\hline \multicolumn{1}{|c|}{ Tipe Red Flag } & \multicolumn{1}{c|}{ Indikator Metacognitive Myopia } \\
\hline $\begin{array}{l}\text { Lack of Progress } \\
\text { (LP-E) }\end{array}$ & $\begin{array}{l}\text { Subjek tidak menyadari bahwa mereka mengalami kesulitan untuk } \\
\text { memvalidasi informasi yang relevan dengan metode yang digunakan. }\end{array}$ \\
\hline $\begin{array}{l}\text { Error Detection (ED- } \\
\text { E) }\end{array}$ & $\begin{array}{l}\text { Subjek tidak menyadari bahwa mereka melakukan kesalahan ketika } \\
\text { memvalidasi informasi yang relevan dengan metode yang digunakan. }\end{array}$ \\
\hline $\begin{array}{l}\text { Anomalous Result } \\
\text { (AR-E) }\end{array}$ & $\begin{array}{l}\text { Subjek tidak menyadari bahwa kesalahan/ketidaksesuaian yang mereka } \\
\text { temukan saat memvalidasi informasi yang relevan dalam penggunaannya } \\
\text { tidak ada. }\end{array}$ \\
\hline
\end{tabular}

Setelah tahap eksplorasi masalah, subjek kemudian merencanakan untuk memecahkan masalah. Pada fase ini, subjek memikirkan pendekatan yang dapat digunakan untuk menemukan solusi. Indikator Metacognitive Myopia pada fase ini dapat dilihat pada Tabel 4. 
Metacognitive Myopia: Bentuk Khusus Kebutaan Metakognitif dalam Konteks Perkuliahan Daring di Era Pandemi, Surya Sari Faradiba, Alifiani, Siti Nurul Hasana

Tabel 4. Indikator Metacognitive Myopia pada fase Perencanaan/Planning $(P)$

\begin{tabular}{|l|l|}
\hline \multicolumn{1}{|c|}{ Tipe Red Flag } & \multicolumn{1}{c|}{ Indikator Metacognitive Myopia } \\
\hline $\begin{array}{l}\text { Lack of Progress } \\
\text { (LP-P) }\end{array}$ & $\begin{array}{l}\text { Subjek tidak menyadari bahwa mereka mengalami kesulitan dalam } \\
\text { memvalidasi berbagai pendekatan untuk memecahkan masalah. }\end{array}$ \\
\hline $\begin{array}{l}\text { Error Detection (ED- } \\
\text { P) }\end{array}$ & $\begin{array}{l}\text { Subjek tidak menyadari bahwa mereka melakukan kesalahan dalam } \\
\text { memvalidasi berbagai pendekatan untuk memecahkan masalah. }\end{array}$ \\
\hline $\begin{array}{l}\text { Anomalous Result } \\
\text { (AR-P) }\end{array}$ & $\begin{array}{l}\text { Subjek tidak menyadari bahwa kesalahan/ketidaksesuaian yang } \\
\text { mereka temukan saat memvalidasi berbagai pendekatan untuk } \\
\text { menyelesaikan masalah tidak ada. }\end{array}$ \\
\hline
\end{tabular}

Pada fase kelima, subjek melakukan rencana pemecahan masalah. Di sini subjek menerapkan pendekatan yang dipilih dan menggabungkan beberapa pendekatan. Indikator Metacognitive Myopia pada fase ini dapat dilihat pada Tabel 5.

Tabel 5. Indikator Metacognitive Myopia pada fase Implementasi/Implementing (I)

\begin{tabular}{|l|l|}
\hline \multicolumn{1}{|c|}{ Tipe Red Flag } & \multicolumn{1}{c|}{ Indikator Metacognitive myopia } \\
\hline $\begin{array}{l}\text { Lack of Progress } \\
\text { (LP-I) }\end{array}$ & $\begin{array}{l}\text { Subjek tidak menyadari bahwa mereka mengalami kesulitan dalam } \\
\text { memvalidasi langkah-langkah penerapan strategi yang dipilih. }\end{array}$ \\
\hline $\begin{array}{l}\text { Error Detection } \text { (ED- } \\
\text { I) }\end{array}$ & $\begin{array}{l}\text { Subjek tidak menyadari bahwa mereka melakukan kesalahan dalam } \\
\text { memvalidasi langkah-langkah penerapan strategi yang dipilih. }\end{array}$ \\
\hline $\begin{array}{l}\text { Anomalous Result } \\
\text { (AR-I) }\end{array}$ & $\begin{array}{l}\text { Subjek tidak menyadari bahwa kesalahan/ketidaksesuaian yang mereka } \\
\text { temukan saat memvalidasi langkah-langkah penerapan strategi yang dipilih } \\
\text { tidak ada. }\end{array}$ \\
\hline
\end{tabular}

Tahap terakhir adalah verifikasi. Pada fase ini, subjek mengevaluasi kegiatan yang berkaitan dengan pendekatan, metode, strategi, prosedur perhitungan dan hasil akhir. Indikator Metacognitive Myopia pada fase ini ada pada Tabel 6 .

Tabel 6. Indikator Metacognitive Myopia pada fase Verifikasi/Verification (V)

\begin{tabular}{|l|l|}
\hline \multicolumn{1}{|c|}{ Tipe Red Flag } & \multicolumn{1}{c|}{ Indikator Metacognitive myopia } \\
\hline $\begin{array}{l}\text { Lack of Progress } \\
\text { (LP-V) }\end{array}$ & $\begin{array}{l}\text { Subjek tidak menyadari bahwa mereka mengalami kesulitan saat } \\
\text { memvalidasi kesesuaian solusi yang telah dihasilkan. }\end{array}$ \\
\hline $\begin{array}{l}\text { Error Detection (ED- } \\
\text { V) }\end{array}$ & $\begin{array}{l}\text { Subjek tidak menyadari bahwa mereka melakukan kesalahan saat } \\
\text { memvalidasi kesesuaian solusi yang telah dihasilkan. }\end{array}$ \\
\hline $\begin{array}{l}\text { Anomalous Result } \\
\text { (AR-V) }\end{array}$ & $\begin{array}{l}\text { Subjek tidak menyadari bahwa kesalahan/ketidaksesuaian yang mereka } \\
\text { temukan saat memvalidasi solusi sebenarnya tidak ada. }\end{array}$ \\
\hline
\end{tabular}

\section{HASIL DAN DISKUSI}

Metakognisi berkaitan dengan ketiga tipe pengetahuan, yaitu: (1) pengetahuan deklaratif, (2) pengetahuan prosedural, dan (3) pengetahuan kondisional dalam pembelajaran (Bulut, 2021; Montero Iii \& Elipane, 2021). Pengetahuan deklaratif mengacu pada pengetahuan tentang fakta dan konsepkonsep matematika yang dimiliki seseorang atau faktor-faktor yang mempengaruhi pemikirannya dan perhatiannya dalam menyelesaikan masalah matematika. Pengetahuan prosedural adalah pengetahuan 
bagaimana melakukan sesuatu, bagaimana melakukan langkah-langkah atau strategi-strategi dalam suatu proses penyelesaian masalah matematika. Pengetahuan kondisional mengacu pada kesadaran seseorang akan kondisi yang mempengaruhi dirinya dalam menyelesaikan masalah, seperti: Kapan suatu strategi seharusnya diterapkan? Mengapa menerapkan suatu strategi? Kapan strategi tersebut digunakan dalam menyelesaikan masalah?.

Selama pembelajaran daring, mahasiswa dituntut untuk lebih mandiri dalam mempelajari suatu konsep matematika yang disajikan di buku siswa. Padahal, analisis buku teks menunjukkan bahwa proses belajar sering fokus hanya pada pengetahuan procedural (Alajmi, 2012; Lenz et al., 2020; Son \& Senk, 2010), yang mungkin menjadi alasan bagi mahasiswa kurang memiliki pengetahuan konseptual. Secara umum, istilah pengetahuan prosedural digunakan untuk menggambarkan pengetahuan tentang operasi dalam arti urutan langkah atau tindakan parsial, yang dilakukan untuk mencapai tujuan tertentu (Rittle-Johnson et al., n.d.).

Lebih lanjut dalam tahap memahami masalah yang telah disajikan dalam penelitian ini, subjek mengalami kesalahan prosedural yang tidak ia sadari, Pada Gambar 1, khususnya bagian kasus I, dapat dilihat bahwa subjek mendefinisikan $f\left(x_{1}\right)=x_{1}$ dan $f\left(x_{2}\right)=x_{2}$ dimana definisi tersebut tidak sesuai dengan definisi pada soal, seharusnya $f(x)=\left\{\begin{array}{c}2 x-1, \text { jika } x \text { bilangan genap } \\ 2 x \text {, jika } x \text { bilangan ganjil }\end{array}\right.$. Sementara itu pada kasus 2, subjek menuliskan $f\left(x_{2}\right)=2 x_{2}-1$ padahal didefinisikan sebelumnya bahwa $x_{2}$ ganjil, maka seharusnya $f\left(x_{2}\right)=2 x_{2}$. Untuk mengonfirmasi Error Detection (ED-U) pada subjek, peneliti melakukan wawancara sebagai berikut:

Peneliti : "Apa yang akan anda buktikan pada masalah pertama?"

Subjek : "Saya akan menunjukkan bahwa fadalah fungsi satu satu"

Peneliti : "Untuk menunjukkan $f$ adalah fungsi satu satu, strategi apa yang akan anda gunakan?"

Subjek : "ada tiga kondisi yang berbeda, kondisi pertama adalah jika $x_{1}$ dan $x_{2}$ bilangan genap, kondisi kedua adalah jika $x_{1}$ genap dan $x_{2}$ ganjil, dan kondisi ketiga adalah jika $x_{1}$ dan $x_{2}$ keduanya adalah ganjil"

Peneliti : "Apakah informasi yang telah diberikan sudah cukup untuk menjawab pertanyaan?"

Subjek : "Sudah, bu, termasuk informasi tentang daerah asal dan daerah hasil yang didefinisikan pada bilangan bulat"

Peneliti : "Menurut anda, fungsi itu apa?"

Subjek : "Himpunan pasangan berurutan bu, sehingga setiap anggota daerah asal berpasangan dengan anggota daerah hasil"

Peneliti : "Apakah anda sudah yakin dengan jawaban yang anda tulis?"

Subjek : "Ya, saya yakin"

Dari cuplikan wawancara dapat diketahui bahwa subjek memiliki pemahaman prosedural dan konseptual yang baik. Namun, subjek masih mengalami kesalahan (error) yang tidak disadarinya 
Metacognitive Myopia: Bentuk Khusus Kebutaan Metakognitif dalam Konteks Perkuliahan Daring di Era Pandemi, Surya Sari Faradiba, Alifiani, Siti Nurul Hasana

pada saat mendefiniskan fungsi padda kasus I dan kasus II. Fenomena ini termasuk red flag jenis Error Detection (ED). ED akan menyebabkan kebutaan metakognitif ketika subjek tidak menyadari adanya kesalahan yang telah dilakukan sehingga subjek melanjutkan proses pemecahan masalah tanpa memeriksa atau mengoreksi kesalahan (Faradiba \& Alifiani, 2020). Senada dengan hal tersebut, dalam penelitian ini ED menjadi indikator metacognitive myopia dimana subjek tidak menyadari adanya kesalahan dalam mendefinisikan fungsi.

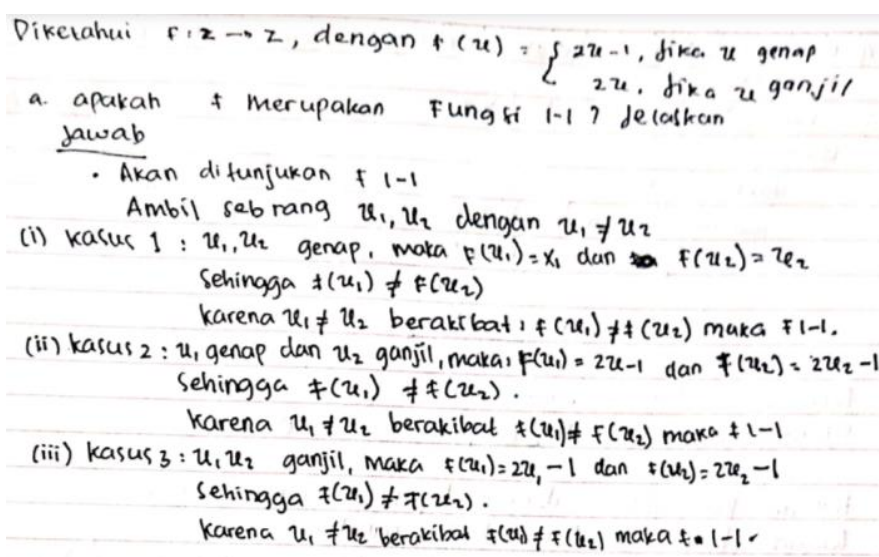

Gambar 1. Hasil Pekerjaan Subjek dalam Membuktikan Fungsi $f$ 1-1

Sementara itu pada Gambar 2 dapat dilihat bahwa subjek menuliskan $x=y$, seharusnya $x=$ $\frac{y+1}{2}$. Sama halnya dengan pada saat menunjukkan bahwa fungsi $f$ adalah fungsi $1-1$. Subjek mengalami kesalahan (error) pada saat mengimplementasikan langkah pemecahan masalah yang telah dipilih. Untuk menunjukkan suatu fungsi adalah onto, perlu dicermati dua kemungkinan yang terjadi, yakni (1) untuk y bernilai genap, dan (2) untuk y bernilai ganjil. Langkah ini sebetulnya sudah sesuai, hanya saja subjek melakukan kesalahan (error) ketika mendefinisikan fungsi, dimana seharusnya mengacu pada definisi fungsi yang telah diketahui.

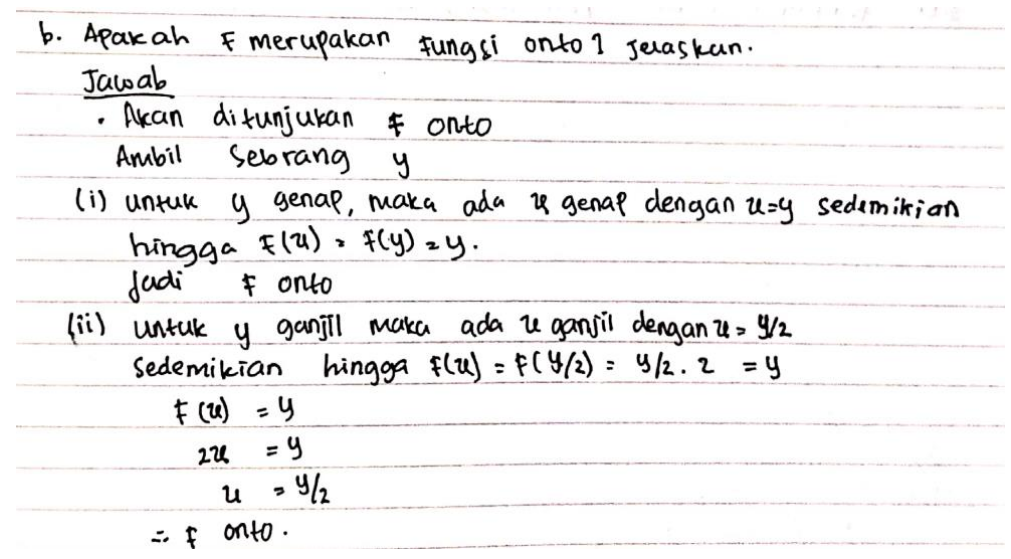

Gambar 2. Hasil Pekerjaan Subjek dalam Membuktikan Fungsi f adalah onto 
Untuk memahami red flag tipe error detection yang dialami oleh subjek dalam tahap implementasi penyelesaian masalah, peneliti melakukan wawancara. Berikut hasil cuplikan wawancara menegenai hal tersebut:

Peneliti : "Apa yang akan anda buktikan pada masalah kedua?"

Subjek : "Saya akan menunjukkan bahwa fadalah fungsi pada (onto)"

Peneliti : "Untuk menunjukkan $f$ adalah fungsi onto, strategi apa yang akan anda gunakan?"

Subjek : "pertama kita ambil sebarang nilai y dimana dalam hal ini ada dua kondisi yang berbeda, kondisi pertama adalah jika y bilangan genap, kondisi kedua adalah jika y ganjil”,

Peneliti : "Apakah informasi yang telah diberikan sudah cukup untuk menjawab pertanyaan?"

Subjek : "Sudah, bu"

Peneliti : "Apakah anda sudah yakin dengan jawaban yang anda tulis?"

Subjek : "Ya, saya yakin"

Pada Gambar 3 menunjukkan hasil akhir subjek dalam menyelesaikan masalah pembuktian fungsi invertible. Dalam hal ini meskipun subjek tidak menyadari bahwa dirinya mengalami kesalahan (error) dalam menyelesaikan pembuktian fungsi $f$ adalah satu satu dan pada (onto), namun kesimpulan akhir yang dituliskan adalah benar, yakni $f$ adalah fungsi yang invertible. Suatu kondisi dimana subjek tidak menyadari bahwa dia mengalami kesalahan (error) dalam mengimplementasikan strategi yang dipilih.

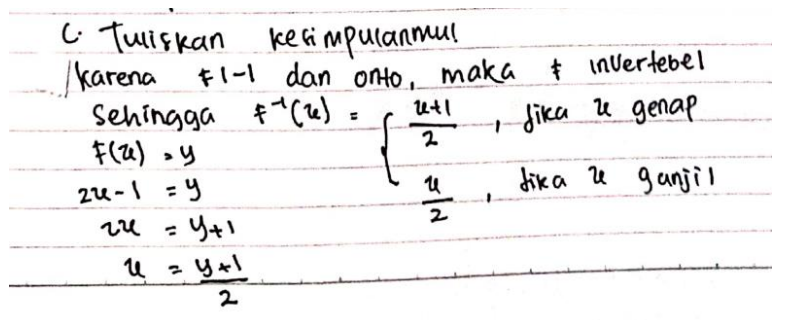

Gambar 3. Hasil Akhir Subjek dalam Menunjukkan bahwa finvertible

Untuk mengeksplorasi metacognitive myopia yang terjadi, peneliti melakukan wawancara dengan subjek pada bagian akhir penyelesaian masalah. Cuplikan wawancara pada bagian ini dapat dilihat sebagai berikut:

Peneliti : "Apa yang akan anda buktikan pada masalah ketiga?"

Subjek : "Sebagai lanjutan dari masalah pertama dan kedua, saya akan menunjukkan bahwa fadalah fungsi invertible",

Peneliti : "Untuk menunjukkan $f$ adalah fungsi invertible, strategi apa yang akan anda 
Metacognitive Myopia: Bentuk Khusus Kebutaan Metakognitif dalam Konteks Perkuliahan Daring di Era Pandemi, Surya Sari Faradiba, Alifiani, Siti Nurul Hasana

gunakan?"

Subjek : "suatu fungsi dikatikan invertible jika bersifat $1-1$ dan onto/pada sehingga jika dua masalah sebelumnya telah terselesaikan maka pada bagian ini saya cukup menyimpulkan saja"

Peneliti : "Apakah anda sudah yakin dengan jawaban yang anda tulis?”

Subjek : "Ya, saya yakin"

\section{KESIMPULAN}

Hasil penelitian menunjukkan bahwa subjek mengalami Metacognitive Myopia yang ditandai dengan adanya Red Flag jenis Error Detection (ED) pada tahap implementasi pemecahan masalah. Fenomena ini dialami oleh mahasiswa yang gagal menyadari adanya kesalahan pada langkah tertentu yang tidak terkait secara langsung dengan pemecahan masalah, sementara pada langkah yang terkait secara langsung tidak ada masalah. Pada kasus ini, mahasiswa menerima informasi begitu saja terkait definisi suatu fungsi dan gagal membedakan apakah informasi tersebut valid atau tidak valid. Namun, subjek tidak mengalami kesalahan dalam menentukan suatu fungsi invertible atau tidak. Subjek memahami syarat suatu fungsi invertible yakni fungsi tersebut harus satu satu dan onto. Penelitian lebih lanjut dibutuhkan untuk memperdalam kajian terkait Metacognitive Myopia dengan melibatkan subjek lebih banyak.

\section{UCAPAN TERIMA KASIH}

Peneliti mengucapkan terimakasih kepada Kementerian Riset dan Teknologi/Badan Riset dan Inovasi Nasional (RISTEK-BRIN) atas hibah dasar unggulan perguruan tinggi (PDUPT) dengan nomor kontrak B/112/E3/RA.00/2021 sehingga penelitian ini dapat terselesaikan dengan baik. Peneliti juga mengucapkan terimakasih kepada Rektor Universitas Islam Malang atas dukungan dan fasilitas selama proses penyelesaian penelitian ini

\section{REFERENSI}

Alajmi, A. H. (2012). How do elementary textbooks address fractions? A review of mathematics textbooks in the USA, Japan, and Kuwait on JSTOR. Educational Studies in Mathematics, 239261. https://www.jstor.org/stable/41413109

Basilaia, G., \& Kvavadze, D. (2020). Transition to Online Education in Schools during a SARSCoV-2 Coronavirus (COVID-19) Pandemic in Georgia. Pedagogical Research, 5(4), em0060. https://doi.org/10.29333/PR/7937

Bulut, A. S. (2021). An Empirical Investigation of Mathematics Learning Approaches and Metacognitive Awareness of Students. Participatory Educational Research, 8(4), 84-102. https://doi.org/10.17275/PER.21.80.8.4 
Cauchemez, S., Ferguson, N. M., Wachtel, C., Tegnell, A., Saour, G., Duncan, B., \& Nicoll, A. (2009). Closure of schools during an influenza pandemic. The Lancet Infectious Diseases, 9(8), 473-481. https://doi.org/10.1016/S1473-3099(09)70176-8

$\begin{array}{lllll}D S M-5 . & \text { (n.d.). } & \text { Retrieved } & \text { August } & \text { 10, }\end{array}$ https://www.psychiatry.org/psychiatrists/practice/dsm

Dwi, S., Prima, S. R., Nur, F., Dikdik Baehaqi Arif, D., \& Fuad, S. (n.d.). Learning analytics to predict student achievement in online learning during Covid-19 mitigation.

Eady, M., \& Lockyer, L. (2013). Tools for learning: technology and teaching strategies. In Senior Deputy Vice-Chancellor and Deputy Vice-Chancellor (Education) - Papers. https://ro.uow.edu.au/asdpapers/403

Ergen, B., \& Kanadli, S. (2017). The Effect of Self-Regulated Learning Strategies on Academic Achievement: A Meta-Analysis Study. Eurasian Journal of Educational Research, 69, 55-74. https://eric.ed.gov/?id=EJ1148778

Faradiba, S. S., \& Alifiani, A. (2020). Metacognitive Blindness in Mathematics Problem-Solving. Journal of Education and Learning Mathematics Research (JELMaR), 1(2), 43-49. https://doi.org/10.37303/JELMAR.V1I2.27

Faradiba, S. S., Sa'dijah, C., Parta, N., \& Rahardjo, S. (2019). LOOKING WITHOUT SEEING: THE ROLE OF METACOGNITIVE BLINDNESS OF STUDENT WITH HIGH MATH ANXIETY. International Journal of Cognitive Research in Science, Engineering and Education (IJCRSEE), 7(2), 53-65. https://doi.org/10.5937/IJCRSEE1902053F

Fiedler, K. (2019). Metacognitive Myopia : Gullibility as a Major Obstacle in the Way of Rational Behavior. The Social Psychology of Gullibility, 123-139. https://doi.org/10.4324/9780429203787-7

Fiedler, K., Hofferbert, J., \& Wöllert, F. (2018). Metacognitive Myopia in Hidden-Profile Tasks: The Failure to Control for Repetition Biases. Frontiers in Psychology, O(JUN), 903. https://doi.org/10.3389/FPSYG.2018.00903

Goos, M., \& Merrilyn. (2002). Understanding Metacognitive Failure. Journal of Mathematical Behavior, 21(3), 283-302. https://doi.org/10.1016/S0732-3123(02)00130-X

Gunawan, G., Suranti, N. M. Y., \& Fathoroni, F. (2020). Variations of Models and Learning Platforms for Prospective Teachers During the COVID-19 Pandemic Period. Indonesian Journal of Teacher Education, 1(2), 61-70. https://journal.publicationcenter.com/index.php/ijte/article/view/95

Hung, M. L., \& Chou, C. (2015). Students' perceptions of instructors' roles in blended and online learning environments: A comparative study. Computers and Education, 81, 315-325. https://doi.org/10.1016/J.COMPEDU.2014.10.022

Irfan, M., Kusumaningrum, B., Yulia, Y., \& Widodo, S. A. (2020). CHALLENGES DURING THE PANDEMIC: USE OF E-LEARNING IN MATHEMATICS LEARNING IN HIGHER EDUCATION. Infinity Journal, 9(2), 147-158. https://doi.org/10.22460/INFINITY.V9I2.P147158 
Lenz, K., Dreher, A., Holzäpfel, L., \& Wittmann, G. (2020). Are conceptual knowledge and procedural knowledge empirically separable? The case of fractions. British Journal of Educational Psychology, 90(3), 809-829. https://doi.org/10.1111/BJEP.12333

Montero Iii, N. A., \& Elipane, L. E. (2021). The Impact of a Metacognitive Intervention using I.M.P.R.O.V.E. Model on Grade 7 Students' Metacognitive Awareness in Mathematics. Turkish Journal of Computer and Mathematics Education (TURCOMAT), 12(3), 3881-3894. https://doi.org/10.17762/TURCOMAT.V12I3.1677

Nakamura, Y., Yoshitomi, K., \& Kawazoe, M. (2018). Distance Learning, E-Learning and Blended Learning in Mathematics Education. Distance Learning, E-Learning and Blended Learning in Mathematics Education, 133-148. http://link.springer.com/10.1007/978-3-319-90790-1

Panggabean, S., \& Harahap, T. H. (2018). Pengaruh Media E-Learning Berbasis Youtube Terhadap Hasil Belajar Mahasiswa Pada Mata Kuliah Analisis Real Prodi Pendidikan Matematika FKIP UMSU. Prosiding SiManTap: Seminar Nasional Matematika Dan Terapan , 25-30. http://bulletin.indoms-acehsumut.org/index.php/simantap/article/view/144

Ridwan, T., \& Umam, A. F. (2021). Pengaruh Media Pembelajaran Google Classroom Dalam Pembelajaran Terhadap Motivasi Belajar Mahasiswa. Cerdika: Jurnal Ilmiah Indonesia, 1(1), 37-46. https://doi.org/10.36418/CERDIKA.V1I1.3

Rittle-Johnson, B., cognition, M. S.-O. handbook of numerical, \& 2015, undefined. (n.d.). Developing conceptual and procedural knowledge of mathematics. Uni-Trier.De. Retrieved November 15, 2021, from https://www.unitrier.de/fileadmin/fb1/prof/PSY/PAE/Team/Schneider/RittleJohnsonSchneiderInPress.pdf

Sari, E. A., Hadiprasetyo, K., Wulandari, A. A., Sari, E. A., Hadiprasetyo, K., Wulandari, A. A., \& Penulis, K. (2021). Learning difficulties of mathematic students on real analysis courses with an online system. Jurnal Math Educator Nusantara: Wahana Publikasi Karya Tulis Ilmiah Di Bidang Pendidikan Matematika, 7(1), 1-11. https://doi.org/10.29407/JMEN.V7I1.14766

Setiawan, A. R. (2020). Scientific Literacy Worksheets for Distance Learning in the Topic of Coronavirus 2019 (COVID-19). https://doi.org/10.35542/OSF.IO/SWJMK

Son, J. W., \& Senk, S. L. (2010). How reform curricula in the USA and Korea present multiplication and division of fractions. Undefined, 74(2), 117-142. https://doi.org/10.1007/S10649-010-92296

Tosepu, R., Gunawan, J., Effendy, D. S., Ahmad, L. O. A. I., Lestari, H., Bahar, H., \& Asfian, P. (2020). Correlation between weather and Covid-19 pandemic in Jakarta, Indonesia. The Science of the Total Environment, 725. https://doi.org/10.1016/J.SCITOTENV.2020.138436

Utami, R. E. (2017). Efektivitas Pembelajaran Kooperatif Tipe Group Investigation Terhadap Kemampuan Berpikir Kritis Mahasiswa Pada Mata Kuliah Analisis Riil. JIPMat, 2(1). https://doi.org/10.26877/JIPMAT.V2I1.1484 